\title{
Association between polymorphisms in DNA repair gene $X R C C I$ and non-melanoma skin cancer risk: a meta-analysis
}

This article was published in the following Dove Press journal:

OncoTargets and Therapy

13 July 2017

Number of times this article has been viewed

\author{
Lei Wangl,* \\ Jia $\mathrm{Xu}^{2, *}$ \\ Baoxue Duan' \\ 'Department of Medical Pathology, \\ Xiangyang No I People's Hospital, \\ Hubei University of Medicine, \\ Xiangyang, Hubei, ${ }^{2}$ Department \\ of Psychiatry, No 447 Hospital of \\ Chinese People's Liberation Army, \\ Xiangyang, Hubei, People's Republic \\ of China
}

*These authors contributed equally to this work
Correspondence: Lei Wang Department of Medical Pathology, Xiangyang No I People's Hospital, Hubei University of Medicine, No 15 Jiefang Road, Xiangyang, Hubei 44I000, People's Republic of China Email wanglei03@yeah.net
Objective: Non-melanoma skin cancer (NMSC) is the most common malignancy with annually rising incidence. The aim of this study was to estimate the association between three coding polymorphisms (Arg399Gln, Arg194Trp, and Arg280His) of the DNA repair gene X-ray repair cross-complementing group 1 (XRCC1) and NMSC susceptibility.

Methods: Online databases were searched to retrieve case-control studies published between January 2000 and November 2016. Pooled odds ratio (OR) and 95\% confidence interval (CI) were employed to assess the strength of association. Overall, 10 relevant studies were finally included for analysis, including 3,143 NMSC patients and 3,540 controls. For each polymorphism of XRCC1 gene, there were 3,050 cases and 3,463 controls for Arg399Gln, 914 cases and 1,182 controls for Arg194Trp, and 279 cases and 413 controls for Arg280His.

Results: Our results showed that these three polymorphisms in the XRCC1 coding region were not associated with increased risk of NMSC in the total studied population. However, subgroup analysis by ethnicities demonstrated that Gln/Arg genotype of Arg399Gln polymorphism was associated with increased risk of NMSC under the heterogeneous model in Asian populations (Gln/Arg vs Arg/Arg: OR $=1.39,95 \% \mathrm{CI}=1.04-1.87, P=0.03$ ); subgroup analysis by tumor types showed that Trp/Trp genotype of Arg194Trp was positively associated with decreased cancer risk in squamous-cell skin cancer (SCC) type under the homogeneous model (Trp/Trp vs Arg/Arg: OR $=0.38,95 \% \mathrm{CI}=0.16-0.92, P=0.03$ ).

Conclusion: Our results suggested that Arg399Gln variant of XRCC1 gene might be a risk factor for NMSC in Asian populations, and Arg194Trp variant of XRCC1 gene might be a protective factor for patients with SCC. In addition, future case-control studies are still needed to further evaluate the effect of XRCC1 polymorphisms in NMSC risk.

Keywords: non-melanoma skin cancer, XRCC1, polymorphism, meta-analysis, DNA repair, risk factor

\section{Introduction}

Skin cancer is one of the most frequent malignant diseases that arise from the skin in humans. ${ }^{1}$ It is categorized into three main types: basal-cell skin cancer (BCC), squamous-cell skin cancer (SCC), and melanoma. ${ }^{2}$ Non-melanoma skin cancer (NMSC) is the most commonly diagnosed cancer in white-skinned individuals with a worldwide increasing incidence. ${ }^{3}$ It comprises BCC and SCC, as well as a host of rare tumors. ${ }^{4}$ BCC and SCC together account for 95\%-98\% of all NMSC cases: the former is characterized by local invasiveness with rare metastasis; the latter has a higher metastatic potential and is responsible for the majority of deaths from NMSC. ${ }^{5}$ The incidence of NMSC has been rising by 3\%-8\% per year since 1960 , with as much as $300 \%$ 
increase in the past 2 decades. ${ }^{6}$ Moreover, recent estimates demonstrate that more cases of NMSC have occurred in the past 30 years than all other forms of cancer combined. ${ }^{7}$ The rising incidence rates of NMSC are probably caused by a combination of increased exposure to ultraviolet (UV) or sun light, ozone depletion, genetics, and immune suppression. ${ }^{8}$ There are many approaches to the management of NMSC, ${ }^{9}$ but the current treatment is limited due to low complete clearance rates. ${ }^{10}$ In addition, treatment of NMSC is substantial and increasing, posing a considerable burden on the health care system. ${ }^{11}$ Therefore, there is an urgent need to identify particular biomarkers that can predict this disease and guide the treatment options.

Various types of DNA damage could promote the development of human diseases. ${ }^{12}$ DNA repair is a complicated biological process that maintains genome stability. ${ }^{13}$ Epidemiologic research has found that genetic variants of DNA repair genes might be involved in cancer development. ${ }^{14}$ $\mathrm{X}$-ray repair cross-complementing group 1 (XRCCl) gene, located at chromosome $19 \mathrm{q} 13.2$, is a key component of base excision repair (BER) and is required for genetic stability. ${ }^{15}$ It is required for repair in both DNA single-strand break repair and BER pathways and acts primarily as a scaffold protein that facilitates the assembly of multi-protein complexes and coordinating steps during damage. ${ }^{16} \mathrm{XRCC} 1$ is thought to play the repair role through protein-protein interactions or by direct contact with DNA. ${ }^{17}$ Evidence has shown that polymorphisms in DNA repair genes could influence individual DNA repair capacity. ${ }^{18}$ Genetic polymorphisms of $X R C C 1$ gene might contribute to impair DNA repair, thus playing a role in heightening the risk of NMSC. Three main single nucleotide polymorphisms (SNPs) in the coding region of XRCC1 gene have been identified: amino acid substitution between arginine and glutamine at codon 399 (Arg399Gln, G to A base change, SNP number: rs25487) in exon 10, arginine and tryptophan at codon 194 (Arg194Trp, C to T base change, SNP number: rs1799782) in exon 6, and arginine and histidine at codon 280 (Arg280His, G to A base change, SNP number: rs25489) in exon 9. The 399Gln allele, located in the C-terminal functional domain, was shown to be associated with altering the phenotype of the XRCC1 protein $;{ }^{19}$ the 194Trp variant, located in the linker region of the $\mathrm{N}$-terminal functional domain, appeared to protect against genotoxic effects; ${ }^{20}$ the $280 \mathrm{His}$, located in the proliferating cell nuclear antigenbinding region, was suggested to impair and decrease DNA repair ability. ${ }^{21}$ All these changes in conserved protein sites may alter the BER capacity and affect protein function, thus increasing the chances of DNA damage..$^{22,23}$
Although several studies have identified these three SNPs in the $X R C C 1$ gene and NMSC risk, the results still remain inconclusive. In addition, the incidence of NMSC varies widely worldwide based on geographical distribution with the highest rates in Australia and the lowest rates in parts of Africa. ${ }^{24}$ Therefore, we conducted the present meta-analysis to systematically review all the published articles on this issue and to obtain a relatively reliable result.

\section{Materials and methods Search strategy}

We searched the online databases of PubMed, Medline, Web of Science, and Embase to retrieve relevant articles published between January 2000 and November 2016. The Medical Subject Heading (MeSH) terms were "skin cancer or non-melanoma skin cancer", "basal-cell skin cancer or squamous-cell skin cancer", "DNA repair gene or X-ray repair cross-complementing group 1 or XRCC1", and "polymorphism or single nucleotide polymorphism or variant". We manually checked the references of retrieved articles to obtain more sources. Our study included articles written only in the English language. If the same authors had published more than one article on the same subject among the same participants, then only the most complete study was included in this meta-analysis.

\section{Criteria for article screening}

The articles that met the following criteria were included in the study: 1) case-control studies evaluating the relationship between XRCC1 polymorphisms and NMSC susceptibility, 2) studies in which NMSC was confirmed in patients by experienced pathologists, and controls were agematched unrelated participants without any type of cancer, 3 ) studies in which the results were expressed as odds ratio (OR) with corresponding 95\% confidence interval (CI), and 4) studies in which the genotype distribution of controls for a certain polymorphism was in Hardy-Weinberg Equilibrium (HWE). Studies whose data could not be extracted, those with duplicated data, and reviews or conference papers were excluded.

\section{Qualification assessment and data extraction}

According to the Reporting Items for Systematic Reviews and Meta-Analyses (PRISMA) statement, ${ }^{25}$ two authors independently estimated the quality of extracted articles. Any disagreement was resolved by discussing with the third author. Each item reached a final consensus. The following information was retrieved: the name of first 
author, publication year, country, ethnicity, mean age of patients and mean age of controls, total number of cases and controls, tumor types, and genotyping methods.

\section{Statistical analyses}

Statistical analyses were carried out using Review Manager (Revman, version 5.3) software. ${ }^{26}$ The association between XRCC1 polymorphisms and NMSC risk was evaluated by OR with $95 \% \mathrm{CI}$. The significance of the pooled OR was determined by $Z$ test ( $P<0.05$ was considered significant). For each genetic variant, allelic model, homogeneous model, heterogeneous model, domain model, and recessive model were calculated. Cochran's $Q$ test and $I^{2}$ test were employed to evaluate the heterogeneity of the included articles; ${ }^{27,28}$ random-effect model was used when the $P$-value of Cochran's $Q$ test was $<0.10$ and $I^{2}>50 \%$; otherwise, the fixed-effect model was used. To assess whether our results were substantially influenced by the presence of any individual study, we conducted a sensitivity analysis by systematically removing each study and recalculating the significance of the results. The funnel plot was performed to examine the publication bias.

\section{Results}

\section{Characteristics of eligible studies}

We firstly identified 106 relevant articles. After applying the inclusion and exclusion criteria, a total of 10 articles were finally selected, including 6,683 participants (3,143 NMSC patients and 3,540 controls). Figure 1 shows the selection process of this meta-analysis. The 10 articles included were conducted in 10 different countries: UK, ${ }^{29}$ Denmark, ${ }^{30,31}$ USA, ${ }^{32}$ Sweden/Finland, ${ }^{33}$ Sweden, ${ }^{34}$ Korea, ${ }^{35}$ Japan, ${ }^{36}$ Germany, ${ }^{37}$ and Taiwan (China). ${ }^{38}$ Three were conducted in Asian populations and seven in Caucasian populations. The sample size ranged from 40 to 1,176 . The genotypes of XRCC1 polymorphisms were determined using three methods. The genotype distributions of the controls of all studies were in agreement with HWE $(P>0.05)$. The main characteristics of the studies included are presented in Table 1.

\section{Association between XRCCI Arg399GIn polymorphism and NMSC susceptibility}

The summary of the test for association and test for heterogeneity of this meta-analysis is shown in Table 2. All these 10 articles concerned the effect of XRCC1 Arg399Gln polymorphism in NMSC risk, including 3,050 cases and 3,463 controls. No significant between-study heterogeneity was observed, and the fixed-effect model was employed. Our statistical analyses found that XRCC1 Arg399Gln polymorphism was not associated with increased risk of NMSC under the allelic model (Gln vs Arg: OR $=0.97,95 \%$ $\mathrm{CI}=0.90-1.05, P=0.42$ ) as shown in Figure 2. This insignificance was detected in other genetic models as well $(\mathrm{Gln} / \mathrm{Gln}$ vs Arg/Arg: $\mathrm{OR}=0.90,95 \% \mathrm{CI}=0.77-1.06, P=0.20 ; \mathrm{Gln} / \mathrm{Arg}$ vs Arg/Arg: $\mathrm{OR}=1.02,95 \% \mathrm{CI}=0.92-1.14, P=0.69 ; \mathrm{Gln} /$ $\mathrm{Gln}+\mathrm{Gln} / \mathrm{Arg}$ vs Arg/Arg: $\mathrm{OR}=0.99,95 \% \mathrm{CI}=0.90-1.10$, $P=0.89 ; \mathrm{Gln} / \mathrm{Gln}$ vs $\mathrm{Gln} / \mathrm{Arg}+\mathrm{Arg} / \mathrm{Arg}: \mathrm{OR}=0.90,95 \%$ $\mathrm{CI}=0.77-1.04, P=0.16)$.

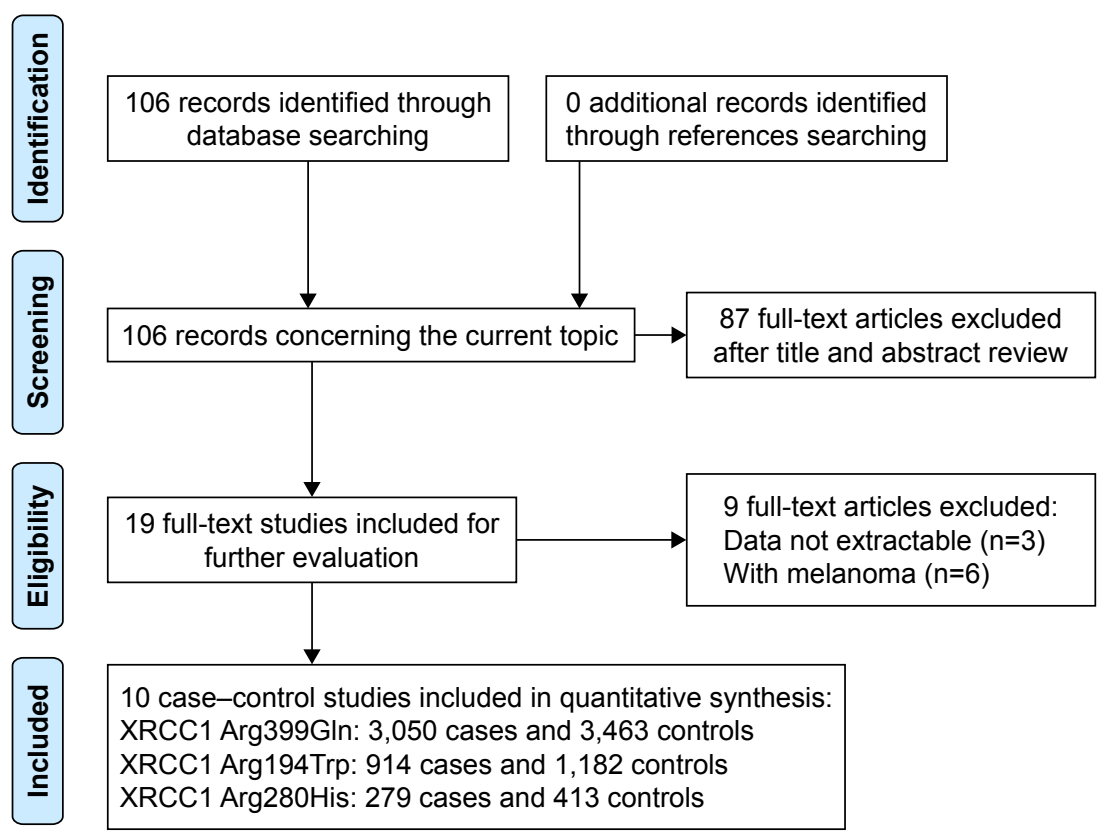

Figure I Selection process of all eligible articles of this meta-analysis. 
Table I The detailed characteristics of all studies included in this meta-analysis

\begin{tabular}{|c|c|c|c|c|c|c|c|c|c|}
\hline \multirow[t]{2}{*}{ Author } & \multirow[t]{2}{*}{ Year } & \multirow[t]{2}{*}{ Country (ethnicity) } & \multicolumn{2}{|c|}{ Mean age (years) } & \multicolumn{2}{|c|}{ Sample size } & \multirow[t]{2}{*}{ Tumor types } & \multirow{2}{*}{$\begin{array}{l}\text { Genotyping } \\
\text { method }\end{array}$} & \multirow{2}{*}{$\begin{array}{l}\text { HWE in } \\
\text { controls }\end{array}$} \\
\hline & & & Cases & Controls & Cases & Controls & & & \\
\hline Nelson et $\mathrm{a}^{29}$ & 2002 & UK (Caucasians) & - & - & 745 & 431 & $\mathrm{BCC}+\mathrm{SCC}$ & PCR-RFLP & 0.185 \\
\hline Yin et al ${ }^{30}$ & 2002 & Denmark (Caucasians) & $20-60$ & $20-60$ & 63 & 97 & $\mathrm{BCC}$ & SNaPshot & 0.774 \\
\hline Yin et $\mathrm{al}^{31}$ & 2003 & Denmark (Caucasians) & $<50$ & $<50$ & 20 & 20 & $\mathrm{BCC}$ & PCR-RFLP & 0.983 \\
\hline Han et $\mathrm{al}^{32}$ & 2005 & USA (Caucasians) & 64.7 & 64.5 & 586 & 874 & $\mathrm{BCC}+\mathrm{SCC}$ & Sequencing & 0.161 \\
\hline Festa et $\mathrm{a}^{33}$ & 2005 & Sweden/Finland (Caucasians) & - & - & 197 & 548 & $\mathrm{BCC}$ & PCR-RFLP & 0.973 \\
\hline Thirumaran et $\mathrm{al}^{34}$ & 2006 & Sweden (Caucasians) & $63.5 \pm 11.7$ & $60.0 \pm 11.8$ & 529 & 533 & $\mathrm{BCC}$ & Sequencing & 0.838 \\
\hline Kang et $\mathrm{a}^{35}$ & 2007 & Korea (Asian) & $68.98 \pm 12.6$ & $46.42 \pm 16.6$ & 212 & 207 & $\mathrm{BCC}+\mathrm{SCC}$ & PCR-RFLP & 0.673 \\
\hline Chiyomaru et $\mathrm{a}^{36}$ & 2012 & Japan (Asian) & $72.9 \pm 12.2$ & $66.1 \pm 13.7$ & 103 & 93 & $\mathrm{BD}+\mathrm{BCC}+\mathrm{SCC}$ & PCR-RFLP & 0.097 \\
\hline Surdu et $\mathrm{al}^{37}$ & 2014 & Germany (Caucasians) & $30-79$ & $30-79$ & 618 & 527 & $\mathrm{BCC}+\mathrm{SCC}$ & Sequencing & 0.838 \\
\hline Hsu et $\mathrm{al}^{38}$ & 2015 & China Taiwan (Asian) & $56.13 \pm 6.87$ & $54.38 \pm 6.26$ & 70 & 210 & $\mathrm{BCC}+\mathrm{SCC}+\mathrm{BD}$ & PCR-RFLP & 0.156 \\
\hline
\end{tabular}

Note: The data are presented as mean values \pm standard deviation.

Abbreviations: -, not available; BCC, basal-cell skin cancer; SCC, squamous-cell skin cancer; BD, Bowen's diseases; PCR-RFLP, polymerase chain reaction-restriction fragment length polymorphism; HWE, Hardy-Weinberg equilibrium.

Subgroup analysis by ethnicities showed that only Gln/ Arg genotype of this variant was significantly correlated with increased risk of NMSC under the heterogeneous model in Asian populations (Gln/Arg vs Arg/Arg: OR=1.39, $95 \% \mathrm{CI}=1.04-1.87, P=0.03$ ) as shown in Figure 3. This positive relationship was not found in other genetic models. Moreover, no significant relationship was found between XRCC1 Arg399Gln variant and NMSC risk under any genetic models in Caucasian populations $(P>0.05)$. Subgroup analysis by NMSC types showed that XRCC1 Arg399Gln variant was not associated with NMSC risk in both BCC and SCC types.

\section{Association between XRCCI Arg 194Trp polymorphism and NMSC susceptibility}

Four articles focused on this genetic variant, containing 914 cases and 1,182 controls. The frequency of Trp allele was a little higher in the patient group than that in the control group (14.6\% vs $12.6 \%)$, but statistical analyses did not detect significant association between XRCC1 Arg194Trp variant and NMSC risk under the five genetic models as shown in Table 2. Subgroup analysis by ethnicities showed that XRCC1 Arg194Trp polymorphism was not associated with NMSC risk among Asian and Caucasian populations $(P>0.05)$. Subgroup analysis by NMSC types showed that Trp/Trp genotype was positively associated with decreased cancer risk in SCC type under the homogeneous model (Trp/Trp vs Arg/Arg: OR $=0.38,95 \%$ $\mathrm{CI}=0.16-0.92, P=0.03)$ as shown in Figure 4. However, this correlation was not found in patients with BCC type.

\section{Association between XRCCI Arg280His polymorphism and NMSC susceptibility}

Two articles included 279 cases and 413 controls. Our results showed that XRCC1 Arg280His polymorphism was not associated with NMSC risk under each genetic model (His vs Arg: $\mathrm{OR}=0.88,95 \% \mathrm{CI}=0.38-2.05, P=0.78$; His/His vs Arg/Arg: $\mathrm{OR}=0.87,95 \% \mathrm{CI}=0.21-3.50, P=0.84$; His/Arg vs Arg/Arg: OR $=0.97,95 \% \mathrm{CI}=0.48-1.95, P=0.93$; His/ His + His/Arg vs Arg/Arg: OR $=0.92,95 \% \mathrm{CI}=0.41-2.07$, $P=0.84$; His/His vs His/Arg + Arg/Arg: OR $=0.87,95 \%$ $\mathrm{CI}=0.21-3.53, P=0.84$ ).

\section{Sensitivity analysis and publication bias}

We systematically omitted each single article one at a time to verify whether our results were influenced by each included study. Our results showed that the pooled ORs were not significantly changed. The funnel plot was used to assess the publication bias of the literature. All genetic comparisons in our study showed no evidence of publication bias as shown in Figure 5, which indicates that there was no publication bias in the present meta-analysis.

\section{Discussion}

In this meta-analysis, we screened 10 relevant articles in total. We found that Arg399Gln, Arg194Trp, and Arg280His polymorphisms of the $X R C C 1$ gene were not associated with NMSC risk in the total studied populations. However, subgroup analysis showed that only Gln/Arg genotype of XRCC1 Arg399Gln variant was significantly correlated with increased risk of NMSC in Asian populations, and Trp/ Trp genotype of XRCC1 Arg194Trp variant was positively associated with decreased risk of SCC type. Our results were not consistent with the previous meta-analysis, which studied the association between polymorphisms of the $\mathrm{XRCCl}$ gene and skin cancer risk, and showed that no significant association was observed in stratified analyses of Arg399Gln and Arg194Trp polymorphisms and tumor type (SCC, BCC, and melanoma). ${ }^{39}$ 
Table 2 Meta-analysis and stratified analyses of Arg399Gln, Arg194Trp, and Arg280His in the coding region of XRCCI gene with NMSC risk under each genetic model

\begin{tabular}{|c|c|c|c|c|c|c|c|c|}
\hline \multirow[t]{2}{*}{ SNPs } & \multirow[t]{2}{*}{ Group } & \multirow[t]{2}{*}{$\mathbf{N}$} & \multirow[t]{2}{*}{ Comparisons } & \multicolumn{2}{|c|}{ Test of association } & \multicolumn{3}{|c|}{ Test of heterogeneity } \\
\hline & & & & OR $(95 \% \mathrm{Cl})$ & $P$-value & $I^{2}(\%)$ & $\mathbf{P h}$ & Model \\
\hline \multirow[t]{25}{*}{ Arg399GIn } & & 10 & Gln vs Arg & $0.97(0.90-1.05)$ & 0.42 & 26 & 0.21 & $\mathrm{~F}$ \\
\hline & & & Gln/Gln vs Arg/Arg & $0.90(0.77-1.06)$ & 0.20 & 22 & 0.24 & $\mathrm{~F}$ \\
\hline & & & Gln/Arg vs Arg/Arg & $1.02(0.92-1.14)$ & 0.69 & 0 & 0.46 & $\mathrm{~F}$ \\
\hline & & & $\mathrm{Gln} / \mathrm{Gln}+\mathrm{G} \ln / \mathrm{Arg}$ vs Arg/Arg & $0.99(0.90-1.10)$ & 0.89 & 5 & 0.40 & $\mathrm{~F}$ \\
\hline & & & $\mathrm{Gln} / \mathrm{Gln}$ vs $\mathrm{Gln} / \mathrm{Arg}+\mathrm{Arg} / \mathrm{Arg}$ & $0.90(0.77-1.04)$ & 0.16 & 28 & 0.18 & $\mathrm{~F}$ \\
\hline & Asian & 3 & Gln vs Arg & $1.04(0.70-1.55)$ & 0.85 & 70 & 0.04 & $\mathrm{R}$ \\
\hline & & & Gln/Gln vs Arg/Arg & $0.94(0.43-2.05)$ & 0.88 & 61 & 0.07 & $\mathrm{R}$ \\
\hline & & & Gln/Arg vs Arg/Arg & $1.39(1.04-1.87)$ & 0.03 & 0 & 0.70 & $\mathrm{~F}$ \\
\hline & & & $\mathrm{Gln} / \mathrm{Gln}+\mathrm{G} \ln / \mathrm{Arg}$ vs Arg/Arg & $1.26(0.96-1.66)$ & 0.10 & 38 & 0.20 & $\mathrm{~F}$ \\
\hline & & & $\mathrm{Gln} / \mathrm{Gln}$ vs $\mathrm{Gln} / \mathrm{Arg}+\mathrm{Arg} / \mathrm{Arg}$ & $0.83(0.4 I-I .70)$ & 0.61 & 57 & 0.10 & $\mathrm{R}$ \\
\hline & Caucasians & 7 & Gln vs Arg & $0.95(0.88-1.03)$ & 0.24 & 0 & 0.67 & $\mathrm{~F}$ \\
\hline & & & Gln/Gln vs Arg/Arg & $0.90(0.76-1.07)$ & 0.22 & 5 & 0.39 & $\mathrm{~F}$ \\
\hline & & & Gln/Arg vs Arg/Arg & $0.98(0.87-1.09)$ & 0.67 & 0 & 0.78 & $\mathrm{~F}$ \\
\hline & & & $\mathrm{Gln} / \mathrm{Gln}+\mathrm{G} \ln / \mathrm{Arg}$ vs Arg/Arg & $0.96(0.86-1.07)$ & 0.42 & 0 & 0.82 & $\mathrm{~F}$ \\
\hline & & & Gln/Gln vs Gln/Arg + Arg/Arg & $0.91(0.77-1.06)$ & 0.23 & 23 & 0.25 & $\mathrm{~F}$ \\
\hline & $\mathrm{BCC}$ & 9 & Gln vs Arg & $0.97(0.90-1.06)$ & 0.51 & 40 & 0.10 & $\mathrm{~F}$ \\
\hline & & & Gln/Gln vs Arg/Arg & $0.89(0.74-1.06)$ & 0.20 & 2 & 0.42 & $\mathrm{~F}$ \\
\hline & & & Gln/Arg vs Arg/Arg & $1.04(0.92-1.17)$ & 0.52 & 45 & 0.07 & $\mathrm{~F}$ \\
\hline & & & $\mathrm{G} \ln / \mathrm{Gln}+\mathrm{G} \ln / \mathrm{Arg}$ vs Arg/Arg & $1.00(0.90-1.12)$ & 0.94 & 46 & 0.06 & $\mathrm{~F}$ \\
\hline & & & $\mathrm{Gln} / \mathrm{Gln}$ vs $\mathrm{Gln} / \mathrm{Arg}+\mathrm{Arg} / \mathrm{Arg}$ & $0.89(0.72-1.09)$ & 0.24 & 20 & 0.27 & $\mathrm{~F}$ \\
\hline & SCC & 5 & Gln vs Arg & $0.99(0.78-1.25)$ & 0.92 & 63 & 0.03 & $\mathrm{R}$ \\
\hline & & & Gln/Gln vs Arg/Arg & $0.99(0.56-1.76)$ & 0.98 & 71 & 0.008 & $\mathrm{R}$ \\
\hline & & & Gln/Arg vs Arg/Arg & $0.99(0.82-1.19)$ & 0.88 & 0 & 0.58 & $\mathrm{~F}$ \\
\hline & & & $\mathrm{Gln} / \mathrm{Gln}+\mathrm{G} \ln / \mathrm{Arg}$ vs Arg/Arg & $0.95(0.80-1.13)$ & 0.57 & 19 & 0.30 & $\mathrm{~F}$ \\
\hline & & & $\mathrm{Gln} / \mathrm{Gln}$ vs $\mathrm{G} \ln / \mathrm{Arg}+\mathrm{Arg} / \mathrm{Arg}$ & $0.97(0.57-1.64)$ & 0.90 & 70 & 0.01 & $\mathrm{R}$ \\
\hline \multirow[t]{25}{*}{ Arg 194Trp } & & 4 & Trp vs Arg & $0.98(0.82-1.19)$ & 0.86 & 46 & 0.13 & $\mathrm{~F}$ \\
\hline & & & Trp/Trp vs Arg/Arg & $0.72(0.43-1.22)$ & 0.22 & 0 & 0.88 & $\mathrm{~F}$ \\
\hline & & & Trp/Arg vs Arg/Arg & $1.10(0.72-1.70)$ & 0.65 & 60 & 0.06 & $\mathrm{R}$ \\
\hline & & & Trp/Trp + Trp/Arg vs Arg/Arg & $1.03(0.69-1.54)$ & 0.87 & 58 & 0.07 & $\mathrm{R}$ \\
\hline & & & Trp/Trp vs Trp/Arg + Arg/Arg & $0.72(0.44-1.20)$ & 0.21 & 0 & 0.97 & $\mathrm{~F}$ \\
\hline & Asian & 2 & Trp vs Arg & $0.91(0.61-1.36)$ & 0.64 & 58 & 0.12 & $\mathrm{R}$ \\
\hline & & & Trp/Trp vs Arg/Arg & $0.74(0.4 I-\mid .3 I)$ & 0.30 & 0 & 0.53 & $\mathrm{~F}$ \\
\hline & & & Trp/Arg vs Arg/Arg & $\mathrm{I} .06(0.45-2.5 \mathrm{I})$ & 0.90 & 82 & 0.02 & $\mathrm{R}$ \\
\hline & & & Trp/Trp + Trp/Arg vs Arg/Arg & $0.97(0.47-2.0 \mathrm{I})$ & 0.94 & 78 & 0.03 & $\mathrm{R}$ \\
\hline & & & Trp/Trp vs Trp/Arg + Arg/Arg & $0.74(0.43-1.29)$ & 0.29 & 0 & 0.98 & $\mathrm{~F}$ \\
\hline & Caucasians & 2 & Trp vs Arg & $1.17(0.87-1.56)$ & 0.30 & 0 & 0.34 & $\mathrm{~F}$ \\
\hline & & & Trp/Trp vs Arg/Arg & $0.66(0.18-2.35)$ & 0.52 & 0 & 0.62 & $\mathrm{~F}$ \\
\hline & & & Trp/Arg vs Arg/Arg & $1.27(0.92-1.74)$ & 0.14 & 0 & 0.73 & $\mathrm{~F}$ \\
\hline & & & Trp/Trp + Trp/Arg vs Arg/Arg & $1.22(0.90-1.67)$ & 0.20 & 0 & 0.50 & $\mathrm{~F}$ \\
\hline & & & Trp/Trp vs Trp/Arg + Arg/Arg & $0.64(0.18-2.29)$ & 0.50 & 0 & 0.64 & $\mathrm{~F}$ \\
\hline & $\mathrm{BCC}$ & 4 & Trp vs Arg & $1.02(0.8 \mathrm{I}-1.29)$ & 0.84 & 0 & 0.59 & $\mathrm{~F}$ \\
\hline & & & Trp/Trp vs Arg/Arg & $0.97(0.53-1.77)$ & 0.92 & 0 & 0.80 & $\mathrm{~F}$ \\
\hline & & & Trp/Arg vs Arg/Arg & $\mathrm{I} .06(0.80-1.4 \mathrm{I})$ & 0.68 & 0 & 0.49 & $\mathrm{~F}$ \\
\hline & & & Trp/Trp + Trp/Arg vs Arg/Arg & $1.05(0.80-1.38)$ & 0.73 & 0 & 0.53 & $\mathrm{~F}$ \\
\hline & & & Trp/Trp vs Trp/Arg + Arg/Arg & $1.25(0.70-2.25)$ & 0.46 & 0 & 0.74 & $\mathrm{~F}$ \\
\hline & SCC & 3 & Trp vs Arg & $0.9 I(0.55-1.5 \mathrm{I})$ & 0.71 & 73 & 0.03 & $\mathrm{R}$ \\
\hline & & & Trp/Trp vs Arg/Arg & $0.38(0.16-0.92)$ & 0.03 & 0 & 0.90 & $\mathrm{~F}$ \\
\hline & & & Trp/Arg vs Arg/Arg & I.II (0.52-2.38) & 0.78 & 82 & 0.004 & $\mathrm{R}$ \\
\hline & & & Trp/Trp + Trp/Arg vs Arg/Arg & $0.99(0.49-2.00)$ & 0.98 & 80 & 0.007 & $\mathrm{R}$ \\
\hline & & & Trp/Trp vs Trp/Arg + Arg/Arg & $0.42(0.18-1.00)$ & 0.05 & 0 & & $\mathrm{~F}$ \\
\hline \multirow[t]{5}{*}{ Arg280His } & & 2 & His vs Arg & $0.88(0.38-2.05)$ & 0.78 & 74 & 0.05 & $\mathrm{R}$ \\
\hline & & & $\mathrm{His} / \mathrm{His}$ vs $\mathrm{Arg} / \mathrm{Arg}$ & $0.87(0.21-3.50)$ & 0.84 & 0 & 0.34 & $\mathrm{~F}$ \\
\hline & & & His/Arg vs Arg/Arg & $0.97(0.48-1.95)$ & 0.93 & 58 & 0.12 & $\mathrm{R}$ \\
\hline & & & $\mathrm{His} / \mathrm{His}+\mathrm{His} / \mathrm{Arg}$ vs $\mathrm{Arg} / \mathrm{Arg}$ & $0.92(0.4 I-2.07)$ & 0.84 & 69 & 0.07 & $\mathrm{R}$ \\
\hline & & & His/His vs His/Arg + Arg/Arg & $0.87(0.21-3.53)$ & 0.84 & 0 & 0.38 & $\mathrm{~F}$ \\
\hline
\end{tabular}

Abbreviations: NMSC, non-melanoma skin cancer; SNP, single nucleotide polymorphism; N, number of included studies; OR, odds ratio; Cl, confidence interval; F, fixedeffect model; R, random-effect model; BCC, basal-cell skin cancer; SCC, squamous-cell skin cancer; Ph, $P$-value of heterogeneity. 


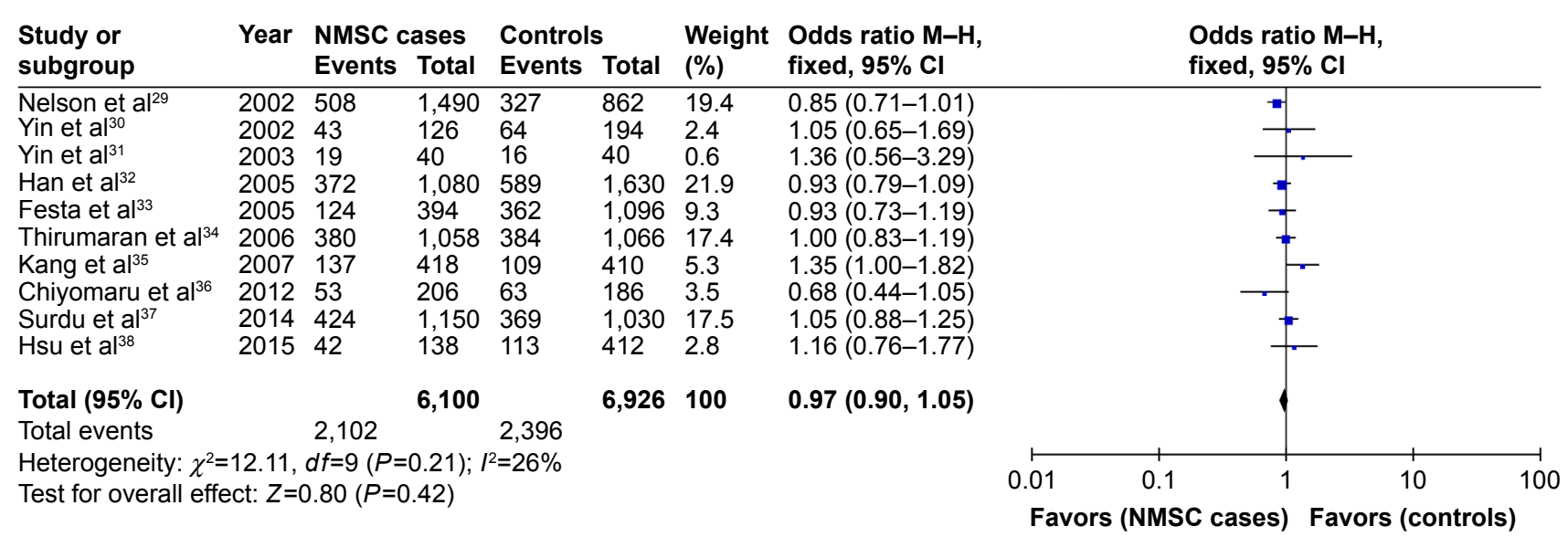

Figure 2 Forest plot of the association between XRCCI Arg399Gln polymorphism and non-melanoma skin cancer risk under allelic model. Abbreviation: NMSC, non-melanoma skin cancer.

Harmful effects of solar UV radiation on human health is one of the causes of NMSC. ${ }^{40}$ Exposure to UV radiation initiates $\sim 90 \%$ of NMSC, causing malignant transformation of keratinocytes and suppression of inflammatory response. A reduced capacity to repair UV-induced DNA damage is one of the underlying molecular mechanisms for sunlightinduced skin carcinogenesis in the general population. ${ }^{41}$ Evidence showed that a low DNA repair capacity was a susceptibility factor for NMSC. ${ }^{42-44}$ The XRCC1 protein, involved in the DNA repair pathway, is essential for the maintenance of genomic stability. ${ }^{45}$ It serves to orchestrate BER via its role as a central scaffolding protein physically associated with DNA ligase III and via its function in recognizing and binding to single-strand breaks. ${ }^{46,47}$ XRCC1 is also involved in the organization of BER into multi-protein complexes of different sizes to DNA damage sites, ${ }^{48}$ and defects in BER are shown to be linked with immunodeficiency, neurodegenerative disorders, and cancer predisposition. $^{49}$

Some studies have shown that polymorphisms in DNA repair genes might change the risk of cancer development. ${ }^{50-52}$ Variant genotypes of $X R C C 1$ gene that cause amino acid substitutions may affect protein structure and gene expression, and impair the interaction of XRCC1 with the other enzymatic proteins, thus altering the BER function. For example, XRCC1 polymorphisms could influence cell responses to X-rays, and Arg399Gln of XRCC1 was shown to be associated with higher levels of DNA breaks, ${ }^{53}$ the polymorphic variant Arg280His exhibited a slightly shorter retention time at DNA breaks. ${ }^{54} \mathrm{XRCC} 1$ polymorphisms might be associated with human cancer and could function as biomarkers of cancer susceptibility: Arg399Gln polymorphism was associated with lung cancer ${ }^{55}$ and breast cancer; ${ }^{56}$ Arg194Trp polymorphism was found to be associated with gastric cancer ${ }^{57}$ and breast cancer; ${ }^{58}$ and Arg280His was associated with invasive cervical cancer ${ }^{59}$ and pancreatic cancer. ${ }^{60}$ A previous review showed that the homozygous variant $(\mathrm{Gln} / \mathrm{Gln})$ of Arg399Gln variant can have 3-4-fold diminished capacity to remove DNA adducts and oxidized DNA damage; Arg280His variant appeared to decrease repair function, but Arg194Trp variant appears to protect against genotoxic effects. ${ }^{20}$ This was consistent with our result. Several studies have identified the role of XRCC1 variants in skin cancer risk. Previous meta-analysis suggested



Figure 3 Forest plot obtained by subgroup analysis based on ethnicity showing the association between XRCCI Arg399Gln polymorphism and non-melanoma skin cancer risk under heterogeneous model in Asian populations.

Abbreviation: NMSC, non-melanoma skin cancer. 


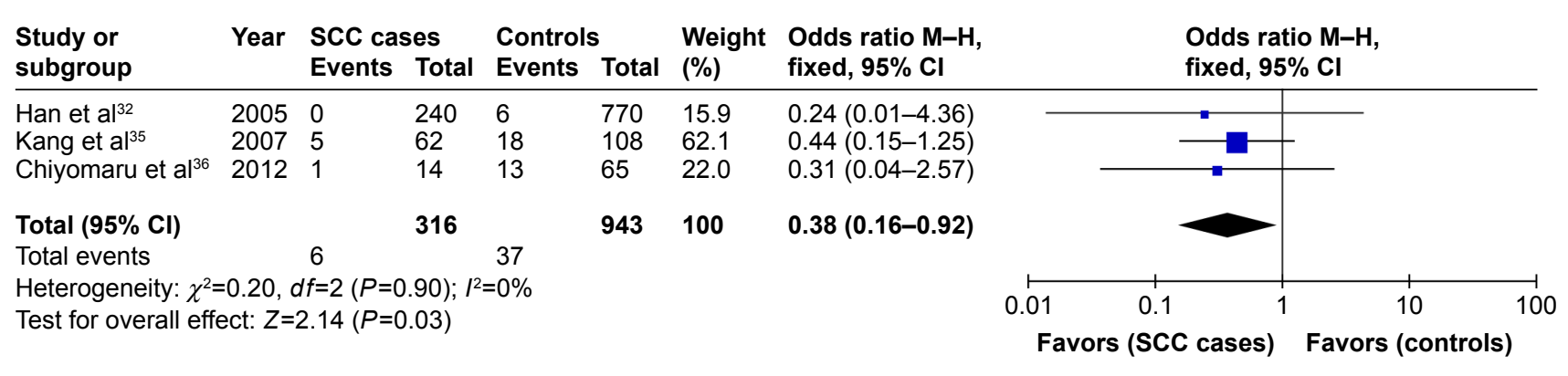

Figure 4 Forest plot obtained by subgroup analysis based on tumor types showing the association between XRCCI Argl94Trp polymorphism and squamous-cell skin cancer risk under homogeneous model.

Abbreviation: SCC, squamous-cell skin cancer.

that XRCC1 Arg399Gln polymorphism was a risk factor for cutaneous melanoma in a population-based subgroup. ${ }^{61}$ Only the 10 studies included in the present meta-analysis analysed the effect of XRCC1 polymorphism in NMSC risk. For instance, a study that included $\sim 300$ Koreans showed that Arg/Gln and Gln/Gln genotypes had an 2-fold increased risk of BCC compared to Arg/Arg individuals, ${ }^{35}$ whereas another study that included 1,000 Caucasians showed that Arg/Arg genotype had significantly reduced risk of both BCC and SCC. ${ }^{29}$ In addition, genes of DNA BER pathway might be evolving as biomarkers for personalized therapies in cancer. ${ }^{62}$ Polymorphisms in DNA repair genes might exert a role in survival, might facilitate response to chemotherapy, and might predict prognosis. Figl et al showed that variants in potential regulatory regions of DNA repair genes might influence disease outcome in melanoma patients and have potentially significant implications for patient surveillance and tailored treatment. ${ }^{63} \mathrm{XRCC} 1$ risk allele may result in resistance to therapy and shorter survival in bladder cancer patients treated with chemotherapy. ${ }^{64}$ XRCC1 Gln allele genotype showed significant prognostic associations in hepatocellular carcinoma. ${ }^{65}$ Bhandaru et al demonstrated



Figure 5 Funnel plot showing XRCCI Arg399GIn polymorphism in non-melanoma skin cancer risk under allelic model.

Abbreviations: OR, odds ratio; SE, standard error. that loss of XRCC1 expression was correlated with the progression of melanoma from dysplastic nevi to primary melanoma and to metastatic melanoma, and with worse overall and disease-specific 5-year and 10-year survival of patients with melanoma. ${ }^{66}$

Several limitations were presented in this meta-analysis. 1) The included studies were conducted only in Asian and Caucasian populations, and other ethnicities were not considered. 2) The number of included studies for a certain SNP such as Arg280His variants was small, which may result in possible bias related to the selection of individual study participants. 3) Other risk factors such as age and gender should be analyzed. 4) The interaction of gene-gene and gene-environment should be included in future research because the combined effect of multiple SNPs in several genes of DNA repair pathways could have a large impact on pathological phenotypes.

\section{Conclusion}

Our results found that Arg399Gln polymorphism of XRCC1 gene might be a risk factor for NMSC in Asian populations and Arg194Trp variant of XRCC1 gene might be a protective factor for SCC patients. However, future large-scale, well-designed studies with more ethnicities are still needed to further investigate the role of XRCC1 polymorphisms in NMSC risk.

\section{Disclosure}

The authors report no conflicts of interest in this work.

\section{References}

1. Lee D. Skin cancer. In: Park JW, Jung Di, editors. Integumentary Physical Therapy. Springer; Berlin Heidelberg. 2016:165-191.

2. Franceschi S, Levi F, Randimbison L, La Vecchia C. Site distribution of different types of skin cancer: new aetiological clues. Int $J$ Cancer. 1996;67(1):24-28.

3. Findlay M, Ally MS. In: Ross D, Farhadieh NW, Bulstrode NC, editors. Wiley Online Library. Non-melanoma skin cancers. Plastic and Reconstructive Surgery: Approaches and Techniques. 2015:100. 
4. Griffin LL, Ali FR, Lear JT. Non-melanoma skin cancer. Clin Med (Lond). 2016;16(1):62-65.

5. Racz J, Joshua AM, Lipa JE, Sun A, Wright FC. Non-melanoma Skin Cancer. Springer International Publishing; Berlin Heidelberg. 2016:225-232.

6. Eisemann N, Waldmann A, Geller AC, et al. Non-melanoma skin cancer incidence and impact of skin cancer screening on incidence. $J$ Invest Dermatol. 2014;134(1):43-50.

7. National cancer institute. Skin Cancer Prevention (PDQ $\left.{ }^{\circledR}\right)$. National Cancer Institute. 2013. Available from: https://www.cancer.gov/types/ skin/patient/skin-prevention-pdq. Accessed June 29, 2017.

8. Leiter U, Eigentler T, Garbe C. Epidemiology of skin cancer. Adv Exp Med Biol. 2014;810:120-140.

9. Micali G, Lacarrubba F, Bhatt K, Nasca MR. Medical approaches to non-melanoma skin cancer. Expert Rev Anticancer Ther. 2013;13(12): 1409-1421.

10. Buchanan MA, Levin B, Veness M. Non-melanoma skin cancer: primary non-surgical therapies and prevention strategies. In: Riffat F, Palme CE, Veness M, editors. Non-Melanoma Skin Cancer of the Head And Neck. India: Springer; 2015:37-51.

11. Guy GP Jr, Machlin SR, Ekwueme DU, Yabroff KR. Prevalence and costs of skin cancer treatment in the U.S., 2002-2006 and 2007-2011. Am J Prev Med. 2014;48(2):183-187.

12. Wang L-E, Wei Q. Nucleotide Excision Repair: DNA Repair Capacity Variability and Cancer Susceptibility. DNA Repair and Cancer: From Bench to Clinic. 2013;288. Available from: https://books.google.co.jp/ books?hl=zh-CN\&lr=\&id=hmPOBQAAQBAJ\&oi=fnd\&pg=PA288\& ots=Pq1v9bUU2m\&sig=YwI2P2hJkGloxN5bT5q-JvWoR_Q\&redir_ $\mathrm{esc}=\mathrm{y} \# \mathrm{v}=$ onepage $\& \mathrm{q} \& \mathrm{f}=$ false. Accessed June 29, 2017.

13. Bernstein C, Anil R, Nfonsam V, Bernstei H. DNA Damage, DNA Repair and Cancer. 2013.

14. Ricceri F, Matullo G, Vineis P. Is there evidence of involvement of DNA repair polymorphisms in human cancer? Mutat Res. 2012;736(1-2): $117-121$.

15. Taylor RM, Thistlethwaite A, Caldecott KW. Central role for the XRCC1 BRCT I domain in mammalian DNA single-strand break repair. Mol Cell Biol. 2002;22(8):2556-2563.

16. London RE. The structural basis of XRCC1-mediated DNA repair. DNA Repair (Amst). 2015;30:90-103.

17. Mok M. Characterization of Protein and DNA Interactions of the Human DNA Repair Protein XRCC1 [doctoral dissertation]. McMaster University, Hamilton, Ontario, Canada; 2016.

18. Cornetta T, Festa F, Testa A, Cozzi R. DNA damage repair and genetic polymorphisms: assessment of individual sensitivity and repair capacity. Int J Radiat Oncol Biol Phys. 2006;66(2):537-545.

19. Lunn RM, Langlois RG, Hsieh LL, Thompson CL, Bell DA. XRCC1 polymorphisms: effects on aflatoxin B1-DNA adducts and glycophorin A variant frequency. Cancer Res. 1999;59(11):2557-2561.

20. Ginsberg G, Angle K, Guyton K, Sonawane B. Polymorphism in the DNA repair enzyme XRCC1: utility of current database and implications for human health risk assessment. Mutat Res. 2011;727(1-2): $1-15$.

21. Takanami T, Nakamura J, Kubota Y, Horiuchi S. The Arg280His polymorphism in X-ray repair cross-complementing gene 1 impairs DNA repair ability. Mutat Res. 2005;582(1-2):135-145.

22. Hung RJ, Hall J, Brennan P, Boffetta P. Genetic polymorphisms in the base excision repair pathway and cancer risk: a HuGE review. Am J Epidemiol. 2005;162(10):925-942.

23. Au WW, Navasumrit $P$, Ruchirawat M. Use of biomarkers to characterize functions of polymorphic DNA repair genotypes. Int J Hyg Environ Health. 2004;207(4):301-313.

24. Lomas A, Leonardi-Bee J, Bath-Hextall F. A systematic review of worldwide incidence of nonmelanoma skin cancer. $\mathrm{Br} J$ Dermatol. 2012;166(5):1069-1080.

25. Moher D, Liberati A, Tetzlaff J, Altman DG; PRISMA Group. Preferred reporting items for systematic reviews and meta-analyses: the PRISMA statement. PLoS Med. 2009;6(7):e1000097.
26. Review Manager (RevMan) [Computer program]. Version 5.3. Copenhagen: The Nordic Cochrane Centre, The Cochrane Collaboration, 2011. Accessed January 5, 2016.

27. Patil KD. Cochran's Q test: exact distribution. J Am Stat Assoc. 1975; 70(349):186-189.

28. Deeks JJ, Altman DG, Bradburn MJ. Matthias E, George DS, Douglas GA. editors. Statistical methods for examining heterogeneity and combining results from several studies in meta-analysis. Systematic Reviews in Health Care: Meta-analysis in Context. 2nd ed. London, UK: Wiley Online Library, BMJ Publishing Group. 2001:285-312.

29. Nelson HH, Kelsey KT, Mott LA, Karagas MR. The XRCC1 Arg399Gln polymorphism, sunburn, and non-melanoma skin cancer: evidence of gene-environment interaction. Cancer Res. 2002;62(1): 152-155.

30. Yin J, Rockenbauer E, Hedayati M, et al. Multiple single nucleotide polymorphisms on human chromosome 19q13.2-3 associate with risk of Basal cell carcinoma. Cancer Epidemiol Biomarkers Prev. 2002; 11(11):1449-1453.

31. Yin J, Vogel U, Gerdes LU, Dybdahl M, Bolund L, Nexo BA. Twelve single nucleotide polymorphisms on chromosome 19q13.2-13.3: linkage disequilibria and associations with basal cell carcinoma in Danish psoriatic patients. Biochem Genet. 2003;41(1-2):27-37.

32. Han J, Colditz GA, Liu JS, Hunter DJ. Genetic variation in XPD, sun exposure, and risk of skin cancer. Cancer Epidemiol Biomarkers Prev. 2005;14(6):1539-1544.

33. Festa F, Kumar R, Sanyal S, et al. Basal cell carcinoma and variants in genes coding for immune response, DNA repair, folate and iron metabolism. Mutat Res. 2005;574(1-2):105-111.

34. Thirumaran RK, Bermejo JL, Rudnai P, et al. Single nucleotide polymorphisms in DNA repair genes and basal cell carcinoma of skin. Carcinogenesis. 2006;27(8):1676-1681.

35. Kang SY, Lee KG, Lee W, et al. Polymorphisms in the DNA repair gene XRCC1 associated with basal cell carcinoma and squamous cell carcinoma of the skin in a Korean population. Cancer Sci. 2007;98(5): 716-720.

36. Chiyomaru K, Nagano T, Nishigori C. XRCC1 Arg194Trp polymorphism, risk of nonmelanoma skin cancer and extramammary Paget's disease in a Japanese population. Arch Dermatol Res. 2012;304(5):363-370.

37. Surdu S, Fitzgerald EF, Bloom MS, et al. Polymorphisms in DNA repair genes XRCC1 and XRCC3, occupational exposure to arsenic and sunlight, and the risk of non-melanoma skin cancer in a European case-control study. Environ Res. 2014;134:382-389.

38. Hsu LI, Wu MM, Wang YH, et al. Association of environmental arsenic exposure, genetic polymorphisms of susceptible genes, and skin cancers in Taiwan. BioMed Res Int. 2015;2015:892579.

39. Zhang H, Li W, Franklin MJ, Dudek AZ. Polymorphisms in DNA repair gene XRCC1 and skin cancer risk: a meta-analysis. Anticancer Res. 2011;31(11):3945-3952.

40. Kricker A, Armstrong BK, English DR. Sun exposure and nonmelanocytic skin cancer. Cancer Causes Control. 1994;5(4):367-392.

41. Wei Q, Matanoski GM, Farmer ER, Hedayati MA, Grossman L. DNA repair capacity for ultraviolet light-induced damage is reduced in peripheral lymphocytes from patients with basal cell carcinoma. J Invest Dermatol. 1995;104(6):933-936.

42. Matta JL, Villa JL, Ramos JM, et al. DNA repair and nonmelanoma skin cancer in Puerto Rican populations. J Am Acad Dermatol. 2003;49(3): 433-439.

43. Wang LE, Li C, Strom SS, et al. Repair capacity for UV light induced DNA damage associated with risk of nonmelanoma skin cancer and tumor progression. Clin Cancer Res. 2007;13(21):6532-6539.

44. Bendesky A, Michel A, Sordo M, et al. DNA damage, oxidative mutagen sensitivity, and repair of oxidative DNA damage in nonmelanoma skin cancer patients. Environ Mol Mutag. 2006;47(7):509-517.

45. Campalans A, Marsin S, Nakabeppu Y, O'Connor TR, Boiteux S, Radicella JP. XRCC1 interactions with multiple DNA glycosylases: a model for its recruitment to base excision repair. DNA Repair (Amst). 2005;4(7):826-835. 
46. Vidal AE, Boiteux S, Hickson ID, Radicella JP. XRCCI coordinates the initial and late stages of DNA abasic site repair through protein-protein interactions. EMBO J. 2001;20(22):6530-6539.

47. Caldecott KW, Aoufouchi S, Johnson P, Shall S. XRCC1 polypeptide interacts with DNA polymerase beta and possibly poly (ADP-ribose) polymerase, and DNA ligase III is a novel molecular 'nick-sensor' in vitro. Nucleic Acids Res. 1996;24(22):4387-4394.

48. Hanssenbauer A, Solvanggarten K, Sundheim O, et al. XRCC1 coordinates disparate responses and multiprotein repair complexes depending on the nature and context of the DNA damage. Environ Mol Mutagen. 2011;52(8):623-635.

49. Wilson DM 3rd, Kim D, Berquist BR, Sigurdson AJ. Variation in base excision repair capacity. Mutat Res. 2011;711(1-2):100-112.

50. Karahalil B, Bohr VA, Wilson DM 3rd. Impact of DNA polymorphisms in key DNA base excision repair proteins on cancer risk. Hum Exp Toxicol. 2012;31(10):981-1005.

51. Jeggo PA, Pearl LH, Carr AM. DNA repair, genome stability and cancer: a historical perspective. Nat Rev Cancer. 2016;16(1):35-42.

52. Zhang K, Zhou B, Wang Y, Rao L, Zhang L. The XRCC1 Arg280His polymorphism contributes to cancer susceptibility: an update by metaanalysis of 53 individual studies. Gene. 2012;510(2):93-101.

53. Gdowiczklosok A, Widel M, Rzeszowskawolny J. The influence of XPD, APE1, XRCC1, and NBS1 polymorphic variants on DNA repair in cells exposed to X-rays. Mutat Res. 2013;755(1):42-48.

54. Berquist BR, Singh DK, Fan J, et al. Functional capacity of XRCC1 protein variants identified in DNA repair-deficient Chinese hamster ovary cell lines and the human population. Nucleic Acids Res. 2010; 38(15):5023-5035.

55. Natukula K, Jamil K, Pingali UR, Attili VS, Madireddy UR. The codon $399 \mathrm{Arg} / \mathrm{Gln}$ XRCC1 polymorphism is associated with lung cancer in Indians. Asian Pac J Cancer Prev. 2013;14(9):5275-5279.

56. Przybylowska-Sygut K, Stanczyk M, Kusinska R, Kordek R, Majsterek I. Association of the Arg194Trp and the Arg399Gln polymorphisms of the XRCC1 gene with risk occurrence and the response to adjuvant therapy among Polish women with breast cancer. Clin Breast Cancer. 2012;13(1):61-68.
57. Chen B, Zhou Y, Yang P, Wu XT. Polymorphisms of XRCC1 and gastric cancer susceptibility: a meta-analysis. Mol Biol Rep. 2012; 39(2):1305-1313.

58. Al Mutairi FM, Alanazi M, Shalaby M, Alabdulkarim HA, Pathan AA, Parine NR. Association of XRCC1 gene polymorphisms with breast cancer susceptibility in Saudi patients. Asian Pac J Cancer Prev. 2013; 14(6):3809-3813.

59. Bajpai D, Banerjee A, Pathak S, Jain S, Singh N. Abstract 5368: Genetic susceptibility to cervical cancer: role of XRCC1. Cancer Res. 2014; 74(19 Suppl):5368.

60. Hou BH, Jian ZX, Cui P, Li SJ, Tian RQ, Ou JR. Association and intragenic single-nucleotide polymorphism interactions of the XRCC1 polymorphisms for pancreatic cancer susceptibility. Pancreas. 2016; 45(4):546-551.

61. Jiang H, Xu W, Zhang F, et al. Quantitative assessment of the association between XRCC1 Arg399Gln and Arg194Trp polymorphisms and risk of cutaneous melanoma. Melanoma Res. 2016;26(3):290-299.

62. Mohan V, Madhusudan S. DNA base excision repair: evolving biomarkers for personalized therapies in cancer. In: Chen C, editor. New Research Directions in DNA Repair. InTechOpen. Rijeka, Croatia. 2013:529-557.

63. Figl A, Scherer D, Nagore E, et al. Single nucleotide polymorphisms in DNA repair genes XRCC1 and APEX1 in progression and survival of primary cutaneous melanoma patients. Mutation Res. 2009; 661(1-2):78-84.

64. Sacerdote C, Guarrera S, Ricceri F, et al. Polymorphisms in the XRCC1 gene modify survival of bladder cancer patients treated with chemotherapy. Int J Cancer. 2013;133(8):2004-2009.

65. Li QW, Lu CR, Ye M, Xiao WH, Liang J. Evaluation of DNA repair gene XRCC1 polymorphism in prediction and prognosis of hepatocellular carcinoma risk. Asian Pac J Cancer Prev. 2012;13(1):191-194.

66. Bhandaru M, Martinka M, Li G, Rotte A. Loss of XRCC1 confers a metastatic phenotype to melanoma cells and is associated with poor survival in patients with melanoma. Pigment Cell Melanoma Res. 2014;27(3):366-375.
OncoTargets and Therapy

\section{Publish your work in this journal}

OncoTargets and Therapy is an international, peer-reviewed, open access journal focusing on the pathological basis of all cancers, potential targets for therapy and treatment protocols employed to improve the management of cancer patients. The journal also focuses on the impact of management programs and new therapeutic agents and protocols on

\section{Dovepress}

patient perspectives such as quality of life, adherence and satisfaction. The manuscript management system is completely online and includes a very quick and fair peer-review system, which is all easy to use. Visit http://www.dovepress.com/testimonials.php to read real quotes from published authors. 